Biogeosciences Discuss., https://doi.org/10.5194/bg-2019-155

Manuscript under review for journal Biogeosciences

Discussion started: 2 May 2019

(c) Author(s) 2019. CC BY 4.0 License.

\title{
ENSO-driven fluctuations in oxygen supply and vertical extent of oxygen-poor waters in the oxygen minimum zone of the Eastern Tropical South Pacific
}

\author{
Yonss Saranga José ${ }^{1}$, Lothar Stramma ${ }^{1}$, Sunke Schmidtko ${ }^{1}$, and Andreas Oschlies ${ }^{1,2}$ \\ ${ }^{1}$ GEOMAR Helmholtz Centre for Ocean Research Kiel, Düsternbrooker Weg 20, 24105 Kiel, Germany \\ ${ }^{2}$ Kiel University, Kiel, Germany \\ Correspondence to: Yonss Saranga José (yjose@ geomar.de)
}

\begin{abstract}
The El Niño Southern Oscillation (ENSO) with its warm (El Niño) and cold (La Niña) phase has strong impacts on marine ecosystems off Peru. This influence extends from changes in nutrient availability to productivity and oxygen levels. While several studies have demonstrated the influence of ENSO events on biological productivity, less is known about their impact on oxygen concentrations. In situ observations along the Peruvian and Chilean coast have shown a strong water column oxygenation during the 1997/1998 strong El Niño event. These observations suggest a deepening of the oxygen minimum zone (OMZ) along the continental shelf. However, due to reduced spatial coverage of the existing in situ observations, no studies have yet demonstrated the OMZ response to El Niño events in the whole Eastern Tropical South Pacific (ETSP). Furthermore, most studies have focused on El Niño events. Much less attention was given to the oxygen dynamics under La Niña influence. Here, we provide a comprehensive analysis of the ENSO influence on OMZ dynamics. Interannual variability of the OMZ during the period 1990-2010 is derived from a regional coupled physical-biogeochemical model forced with realistic atmospheric and lateral boundary conditions. Our results show a reduction of the vertical extent and a deepening of suboxic waters (SW) during the El Niño phase. During the La Niña phase, there is a vertical expansion of SW. These fluctuations in OMZ extent are due to changes in oxygen supply into its core depth mainly from lateral margins. During the El Niño phase, the enhanced lateral oxygen supply from the subtropics is the main reason for the reduction of SW in both coastal and offshore regions. During the La Niña phase, the oxygenated subtropical waters are blocked by the poleward transport along the southern margin of the OMZ. Consequently, oxygen concentrations within the OMZ are reduced and suboxic conditions expand during La Niña. The detailed analysis of transport pathways presented here provides new insights into how ENSO variability affects the oxygen-sensitive marine biogeochemistry of the ETSP.
\end{abstract}

\section{Introduction}

The Eastern Tropical South Pacific (ETSP) has long been known for hosting waters with very low oxygen concentrations at intermediate depths (Chavez et al., 2008; Karstensen et al., 2008). This characteristic is a consequence of a weak oxygen supply by physical dynamics as well as a strong export and subsequent decomposition of organic matter resulting from high biological productivity along the coast (Chavez et al., 2008). The high coastal productivity arises from wind-driven upwelling 
Biogeosciences Discuss., https://doi.org/10.5194/bg-2019-155

Manuscript under review for journal Biogeosciences

Discussion started: 2 May 2019

(c) Author(s) 2019. CC BY 4.0 License.

of nutrient-rich deeper water into the surface layers, where the sunlight drives phytoplankton productivity (Chavez et al., 2008).

This coastal upwelling also brings oxygen-depleted subsurface water onto the continental shelf (Chavez et al., 2008). Thus, fluctuations in upwelling strength as well as in large scale physical dynamics are suitable to induce changes in the distribution of oxygen-deficient waters. Oxygen concentrations recorded along the Peruvian coast show a strong interannual variability tightly associated with El Niño Southern Oscillation (ENSO) fluctuations (Hamersley et al., 2007; Graco et al., 2017), a primary driver of physical variability in this region (Chavez et al., 1999; Escribano et al., 2004; Chavez et al., 2008). While the impacts of ENSO events on ocean temperature and productivity have been studied for many years (Philander, 1983; Barber and Chavez, 1983; Escribano et al., 2004; Chavez et al., 1999), impacts on the oxygen minimum zone (OMZ) remains poorly understood. Anomalous warming and cooling conditions and associated changes in wind patterns during ENSO warm (El Niño) and cold (La Niña) phases are responsible for changes in ocean circulation patterns, upwelling strength as well as thermocline depth of the ETSP (Graham and White, 1988; White and Cayan, 2000; Harisson and Larkin, 1998; Chavez et al., 1999). These dynamics might cause changes in the thickness of the oxygen-poor waters as well as in the extent of suboxic conditions prevailing in this region, as suggested by observations (Hamersley et al., 2007; Graco et al., 2017). Such changes in the distribution of oxygenpoor waters might have important implications for understanding changes in marine ecosystems structure (Chavez et al., 2008) and observed ocean deoxygenation (Stramma et al., 2008). The present paper aims at exploring the response of oxygen-poor waters to ENSO perturbations in the whole ETSP. The main goal is to understand: (1) if oxygen-rich waters observed in the region during the 1997/1998 strong El Niño event reach and oxygenate the core waters of the OMZ, (2) if the water column oxygenation is a common pattern during El Niño events and (3) the implications of La Niña events for the OMZ dynamics. These issues are addressed with a coupled physical-biogeochemical model that is used to simulate ocean dynamics during El Niño and La Niña events observed in the ETSP. When compared with in situ observations, the simulated dynamics show a good capability of reproducing the mean state and interannual variability of both physical and biogeochemical dynamics, giving confidence in the results inferred from the model runs.

\section{Materials and Methods}

\subsection{Model configuration}

The physical-biogeochemical dynamics analysed in this work are the results from a high resolution coupled $C R O C O$ (Coastal and Regional Ocean COmmunity model, Shchepetkin and McWilliams (2005)) - BioEBUS (Biogeochemical model developed for the Eastern Boundary Upwelling Systems, Gutknecht et al. (2013)) model. The CROCO model is the new version of the French ROMS_AGRIF model (Shchepetkin and McWilliams, 2005). This model is conceived primarily to resolve the fine scale coastal processes and their interactions with large scale dynamics. It uses a generalized terrain-following vertical coordinate system, which allows a better representation of coastal processes than models with a classical geopotential vertical coordinate (Song and Haidvogel, 1994). BioEBUS is a nitrogen-based pelagic biogeochemical model which simulates the principal plankton communities, with small (nano- picophytoplankton and microzooplankton) and large (diatoms and mesozooplankton, Gutknecht et al. (2013)) organisms. The nutrient pools consist of nitrate, nitrite and ammonium. This model also represents the 
Biogeosciences Discuss., https://doi.org/10.5194/bg-2019-155

Manuscript under review for journal Biogeosciences

Discussion started: 2 May 2019

(c) Author(s) 2019. CC BY 4.0 License.

biogeochemical sinks of dissolved oxygen dynamics, namely zooplankton respiration, organic matter decomposition, ammonium oxidation to nitrite and oxidation of nitrite to nitrate, as well as oxygen production by phytoplankton. Denitrification and anammox are also included in this model. A detailed description of biogeochemical processes can be found in Gutknecht et al. (2013).

5 The ETSP model domain extends from $10^{\circ} \mathrm{N}-33^{\circ} \mathrm{S}$ and $69^{\circ}-118^{\circ} \mathrm{W}$. This model grid has a horizontal resolution of $\frac{1}{12}^{\circ}$ and 32 topography-following vertical levels. Open boundaries are connected toward monthly mean data of temperature, salinity and current velocities from the Simple Ocean Data Assimilation (SODA, Carton et al. (2018)). The SODA reanalysis data, which uses data assimilation, have a horizontal resolution of $\frac{1}{4}^{\circ}$ and 40 vertical levels (Carton et al., 2018). At the surface, the CROCO model is forced by heat fluxes, humidity, precipitation rates, atmospheric and surface ocean temperature from CFSR (Climate Forecast System Reanalysis) data, as well as the winds from CCMP (Cross-Calibrated Multi-Platform) product. CFSR data consist of 6-hourly values of atmospheric dynamics at around $38 \mathrm{~km}$ spatial resolution (Saha et al., 2010). CCMP is an ocean surface wind product at $\frac{1}{4}^{\circ}$ resolution, obtained from Remote sensing Systems and conventional (mooring and ships) observations (Atlas et al., 1996). Oxygen and nitrate boundary and initial conditions for BioEBUS model are obtained from monthly climatology CARS (CSIRO - Commonwealth scientific and industrial research organisation Atlas of Regional Seas) observations (Ridgway et al., 2002). CARS is a mean climatology at $\frac{1}{2}^{\circ}$ obtained by compiling the existing observations. Living biomass (phytoplankton and zooplankton), nitrite and ammonium are set to $0.05 \mu$ mol.1 ${ }^{-1}$ at the surface and decrease exponentially with depth, with depth scaling factor of $100 \mathrm{~m}$. The model simulation covers the period from 1990 to 2010. Initial condition for 1 January 1990 resulted from a 10 year spin-up run with 1990 forcing.

\subsection{Model validation}

\subsubsection{Data products}

Satellite and in situ observations are used to evaluate the simulated physical and biogeochemical dynamics. The circulation patterns are compared against the satellite-derived Mean Dynamic Topography (MDT) from CNES (Centre National d'Études Spatiales) (Rio et al., 2013) and in situ measured mean alongshore velocities at $12^{\circ} \mathrm{S}$ from IMARPE (Instituto del MAR del PEru, Chaigneau et al. (2013)). Temperature fields from MODIS (MODerate Resolution Imaging Spectroradiometers, Kilpatrick et al. (2015)) at $9 \mathrm{~km}$ resolution and CARS are used to evaluate the simulated sea surface and vertical structure of temperature. The simulated biogeochemical dynamics are compared against (1) CARS data for regional mean oxygen distribution and (2) in situ observations taken during the German cruise M91 along the Peruvian coast in December 2012 for nutrients and oxygen vertical structure (Czeschel et al., 2015).

\subsubsection{Model - data comparison}

30 The simulated fields by this model configuration capture key features of the spatial patterns and interannual variability of the dynamics of this region. At the surface, the simulated current system shows similar spatial patterns as the one derived from altimetry (Rio et al. (2013), contours in Figure 1-a,b). The mean surface currents include the westward surface South Equatorial 
Biogeosciences Discuss., https://doi.org/10.5194/bg-2019-155

Manuscript under review for journal Biogeosciences

Discussion started: 2 May 2019

(c) Author(s) 2019. CC BY 4.0 License.

Current (SEC) along the equatorial region, as well as the north-westward Peru oceanic current (POC) and Peru coastal current (PCC) further south (Figure 1-a,b). At mid-depth, the poleward Peru-Chile UnderCurrent dominates the circulation along the Peruvian coast, in very good agreement with the in situ observations (Figure 1-c,d, Chaigneau et al. (2013) ). The simulated sea surface temperature (SST) shows large-scale patterns similar to the MODIS observation (Kilpatrick et al., 2015), exhibiting warmer waters north of the equator and colder water in the south (color in Figure $1 \mathrm{a}, \mathrm{b}$ ). The observed cold water tongue, which extends toward the equator is well represented in the simulated surface temperature. Cold waters are also present along the Peruvian coast in both observation and simulated dynamics, linked to the coastal upwelling induced by favorable alongshore winds (Chavez et al., 2008). These upwelled cold waters can be also seen in the vertical temperature structure, with the onshore uplift of the isotherms (Figure 1-e,f). Vertically, both simulated and observed temperature decrease with depth.

The oxygen distribution at $400 \mathrm{~m}$ depth presents oxygenated waters over the equatorial region (Figure 2-a,b). Oxygen-poor waters occupy the region south of about $4^{\circ} \mathrm{S}$ and north of the equator in the simulation, in good agreement with the observed oxygen distribution (Czeschel et al., 2011, 2015). Oxygen-poor waters are present from $50 \mathrm{~m}$ to $700 \mathrm{~m}$ depth (Figure 2-c,d, Czeschel et al. $(2011,2015))$. The oxycline is shallow along the coast and deepens progressively toward the open ocean.

Interannual variability of simulated SST anomalies (black and red lines Figure 3-a) is largely coherent with the coastal Nino 1+2 region (black and magenta lines in Figure 3-a) and eastern tropical Nino3 region (red line and gray bars in Figure 3-a) SST anomalies from the National Oceanic and Atmospheric Administration (NOAA, Reynolds et al. (2002)). El Niño events appear as maxima and La Niña events as minima in the SST anomalies. Despite the generally good representation of variability in the SST anomalies, the simulated dynamics fails to reproduce the SST peak in the coastal region during the 2008 and 2009/2010 El Niño event (Figure 3-a), as well as the warming of the eastern tropical region during the 1994/1995 El Niño event (Figure 3a). Differences between NOAA SST and modelled SST anomalies are also visible between 2004 and 2005 , where the model fails to simulate the warming in both coastal and eastern Pacific region during the 2004/2005 El Niño event. ENSO events are commonly considered as periods during which the SST anomalies are greater than a threshold value of $\pm 0.5^{\circ} \mathrm{C}$ above average, with El Niño events being the periods of SST anomaly $>0.5^{\circ} \mathrm{C}$ and La Niña phase the periods of SST anomalies $<-0.5^{\circ} \mathrm{C}$ (black dashed lines in Figure 3-a). Using this definition, the 2004/2005 El Niño event (which was a central Pacific El Niño type, Yu and Kim (2013)) is not classified as El Niño year in NOAA's coastal (Nino1+2) and eastern tropical (Nino 3) indices. It is also noticeable that the NOAA SST anomalies exceeding $0.5^{\circ} \mathrm{C}$ in $2009 / 10 \mathrm{El}$ Niño event occur early (around mid 2009 ) and are absent in 2010 (Figure 3-a,b).

The temporal evolution of simulated oxygen (Figure 3-b) also follows the temporal oxygen variability recorded along the Peruvian coast (Dale et al., 2017). Oxygenated waters occupy the sea floor of the continental shelf during the El Niño events, in line with the observed distribution (Figure 3-b, Hamersley et al. (2007); Graco et al. (2017)). Pronounced oxygenation occurs during the 1997/1998 strong El Niño event (Figure 3-b). 
Biogeosciences Discuss., https://doi.org/10.5194/bg-2019-155

Manuscript under review for journal Biogeosciences

Discussion started: 2 May 2019

(c) Author(s) 2019. CC BY 4.0 License.

\section{Results}

\subsection{ENSO-associated fluctuation of the oxygen-poor waters}

We analyse the dynamics of oxygen-poor waters in terms of the suboxic waters (defined here as a waters with oxygen concentrations below $\left.20 \mu \mathrm{mol} .1^{-1}\right)$. The model-derived volume of suboxic waters continuously fluctuates under ENSO influence, i.e. either El Niño or La Nina years, and also in the "normal" non-ENSO years in between (Figure 4 and Figure 5). We start here by analysing the oxygen-poor waters under normal conditions. Under normal conditions, i.e. during periods with small gray bars in Figure 4-a,b, the evolution of the volume of suboxic waters (SW) shows no clear patterns, exhibiting both reductions and increases in the volume of oxygen-poor waters. Water with oxygen levels below $5 \mu$ mol.1 ${ }^{-1}$ occupies a larger volume in the water column (red line in Figure 4-c,d) than waters with $5 \leq \mathrm{O}_{2} \leq 10 \mu$ mol.1 $^{-1}$ (magenta line), $10 \leq \mathrm{O}_{2} \leq 15 \mu$ mol.1 ${ }^{-1}$ (blue line) or $15 \leq \mathrm{O}_{2} \leq 20 \mu \mathrm{mol} .1^{-1}$ (cyan line). With fluctuations of SW volume, oxygen concentration within this layers oscillates, increasing (decreasing) with a reduction (expansion) of SW volume (black line in Figure 4-c,d). The regional structure of the thickness of SW shows a thinner extent on the shelf along the Peruvian coast, in the equatorial region, as well as at the interface between the subtropical gyre and the OMZ (Figure 5-a).

During El Niño events (positive gray patches in Figure 4-a), the volume of SW is markedly reduced in offshore waters (red line in Figure 4-b) and, particularly before year 2004 in the simulated period 1990-2010, also in onshore waters (red line in Figure 4-a). Similar to the dynamics under normal conditions, a significant reduction occurs in the SW volume with oxygen concentration below $5 \mu \mathrm{mol} .1^{-1}$ (red line in Figure 4-c,d). Simultaneously, the oxygen concentration within the SW layer (SWL) increases (black line in Figure 4-c,d). These changes are particularly pronounced during the strong 1997/1998 El Niño event, as revealed by the observations (Hamersley et al., 2007; Graco et al., 2017). This shows that the enhanced oxygen supply reaches the core depth of the OMZ. Despite the general water column oxygenation, SW is still present along the coast (Figure 5-b). Fluctuations in the SW volume are related to changes in its upper and lower margins (Figure 4-e,f). Onshore, SW is located deeper (Figure 4-e) and occupies a smaller volume (Figure 4-a) during El Niño events. This is also the case in the offshore region, where the lower margin of the SW also shoals during El Niño events (red line in Figure 4-f). This finding is in line with the results of Sanchez et al. (1999) and Stramma et al. (2016) who documented a pronounced deepening of oxygenpoor waters along the Peruvian and Chilean coast during the 1997/1998 and 2015 strong El Niño events. These results suggest that the well-oxygenated waters transported eastward by the undercurrents (Stramma et al., 2010; Czeschel et al., 2015) reach and ventilate the core waters of the ETSP-OMZ during El Niño events.

Conversely, during La Niña events (negative gray patches in Figure 4-a,b), the SW volume increases (red line in Figure 4a,b). The expansion of the SW volume is due to both shoaling of the upper (black line in Figure 4-e,f) and deepening of the lower SW margins (red line in Figure 4-e,f). The mean oxygen concentration within the SWL is reduced (black line in Figure 4c,d), intensifying suboxic conditions in the water column (Figure 4-a,b). This intensification of suboxic conditions suggest less ventilation of ETSP-OMZ under La Niña influence.

In addiction to the ENSO-driven fluctuation in SW volume, the simulated dynamics also show a long-term vertical expansion of this layer of oxygen-poor waters (blue line in Figure 4-a,b), in line with the observational study by Stramma et al. (2008). 
Biogeosciences Discuss., https://doi.org/10.5194/bg-2019-155

Manuscript under review for journal Biogeosciences

Discussion started: 2 May 2019

(c) Author(s) 2019. CC BY 4.0 License.

This vertical expansion, which is about $15.7 \%$ onshore and $17.5 \%$ offshore for the 1990 to 2010 period, is related to both shoaling of upper (in about $10.5 \mathrm{~m}$ onshore and $13.5 \mathrm{~m}$ offshore, respectively) and deepening of the lower (in about $29.6 \mathrm{~m}$ onshore and $58.4 \mathrm{~m}$ offshore, respectively) margins of the SW (Figure 4-e,f).

\subsection{Mechanisms involved in the SWL changes}

5 We now explore mechanisms that may explain the SWL changes under ENSO-driven variability. To this extent, we evaluate two potential mechanisms that control the oxygen dynamics within the SWL: oxygen transport across the margins of the SWL and oxygen demand of biogeochemical processes within the SWL. As the position and surface of the lateral and vertical SW margins vary with time, we use for the calculation of the transport a margins of a common volume occupied by the SW within the 1990-2010 time period. Thus, the eastern margin consist of the far east common section occupied by the SW. Biogeochemical processes are calculated within the same common volume. We start by analysing the oxygen transport at the lateral (Figure 6-a,b and Figure 7-a,b) and vertical (Figure 6-c and Figure 7-c) SWL margins. In good agreement with earlier modeling studies for the climatological mean (Duteil et al., 2014a) and interannual variability (Duteil et al., 2014b), the most effective pathway for oxygen supply into the core of suboxic waters turns out to be the lateral transport. Contributions of the vertical oxygen supply to the total oxygen supply into the SWL are more than an order of magnitude lower than the lateral supply.

In normal conditions, the lateral transport in both onshore and offshore regions shows that, on average, a large contribution of the oxygen supply occurs from the western margin (red line in Figure 6-a and Figure 7-a). This supports the view that the eastward Equatorial Undercurrent (EUC) is the dominant pathway for supplying oxygenated tropical waters into the ETSPOMZ (Stramma et al., 2010). The oxygen supply via equatorial waters from the northern OMZ margin appears to be the second most efficient pathway of oxygen supply in this region (blue line in Figure 6-b and Figure 7-b). There is also a supply of oxygen by subtropical waters from the south (red line in Figure 6-b and Figure 7-b), but it is far weaker than the impact from tropical and equatorial waters. These results are in agreement with a recent study by Llanillo et al. (2018), in which the authors suggested a combined contribution of the tropical, equatorial and subtropical waters in the ventilation of the ETSP-OMZ. It is predominantly the intensity of the lateral oxygen supply that changes in line with the intensity of the ENSO events.

El Niño forcing affects onshore and offshore regions differently (positive SST anomalies in Figure 6 and Figure 7): In the onshore region (Figure 6), the eastward oxygen transport across the western OMZ margin weakens during the early stage of every El Niño event (red line in Figure 6-a). This weakening of the eastward transport is related to the weakening of the eastward undercurrent, as observed in strong El Niño events (Firing et al., 1983; Stramma et al., 2016). Further, the weaker eastward oxygen transport coincides with the narrowing of SW volume (red line in Figure 4-a), suggesting a reduced contribution of the tropical pathway as cause for the thinning of the SWL. Across the southern margin (red line in Figure 6-b), the poleward oxygen transport is either reduced or replaced by an equatorward oxygen flux during the early phase of an El Niño. Weakening of the poleward oxygen fluxes coincides with the strong reduction of the SW volume. This suggests that the injection of subtropical oxygenated waters into the OMZ (red line in Figure 6-b) acts as an important factor for the reduction of the SWL in onshore region. The intensity of the lateral oxygen supply from the subtropical region varies significantly across different El Niño 
Biogeosciences Discuss., https://doi.org/10.5194/bg-2019-155

Manuscript under review for journal Biogeosciences

Discussion started: 2 May 2019

(c) Author(s) 2019. CC BY 4.0 License.

events. A pronounced northward supply of oxygenated subtropical waters across the southern margin occurs during the strong and very strong El Niño events (red line in Figure 6-b). This finding suggests that the Peru-coastal current and the subtropical gyre meridional flow, which move oxygen-rich waters of southern origin northward (Llanillo et al., 2018), increase in strength with El Niño intensity. As the oxygen supply through the southern margin weakens (red line in Figure 6-b), oxygen supply becomes effective through the tropical pathway (red line in Figure 6-a). Variations in oxygen transport across the northern margin, which is dominantly equatorward, plays a small role in the reduction of the SW volume (blue line in Figure 6-b). The only exception occurs in the 2008 event, where the magnitude of changes in the meridional oxygen transport in the equatorial region is comparable to the one at the southern margin.

The subtropical pathway of oxygen supply from the south also contributes to the variations in the ventilation of the SW volume in the offshore region, but not in every El Niño event (red line in Figure 7-b). This is the case for the 1993, and the late stages of the 1994/1995 and 2002/2003 events, where there is no oxygen supply from subtropical region into the SWL. Supply of equatorial waters, which is more significant in the offshore than the onshore region, also varies from event to event (blue line in Figure 7-b). It is pronounced in 1992/1993 as well as 1997/1998 events and strongly contributes to the reduction of the SW volume. Oxygen supply through the western margin shows similar patterns as in the onshore region and weakens during the early phase of every El Niño event (red line in Figure 7-a). As for the onshore region, the enhanced supply of subtropical oxygenated waters offshore during El Niño events appears as a major cause for the reduction of SW volume.

During La Niña phases, the oxygen supply to both onshore (Figure 6) and offshore (Figure 7) regions responds in similar ways to the changing ocean dynamics. Oxygen supply via the tropical (red line in Figure 6-a and and Figure 7-a) and equatorial (blue line in Figure 6-b and Figure 7-b) pathways is balanced by the poleward (red line in Figure 6-b and Figure 7-b) and eastward (blue line in Figure 6-a and Figure 7-a) oxygen fluxes through the southern and eastern margins. Thus, the tropicalequatorial oxygen supply pathways are not effective in reducing the volume of SW in this ENSO phase. The poleward oxygen transport across the southern margin blocks the equatorward propagation of the subtropical oxygenated waters (red line in Figure 6-b and Figure 7-b). This suggest that the Peru-coastal current and the subtropical gyre meridional flow, transporting northward southern origin waters (Llanillo et al., 2018), weaken under La Niña influence. In addition, the reduced oxygen supply from the subtropical region (red line in Figure 6-b and Figure 7-b) cause a southward extension of oxygen-poor waters under La Niña influence (Figure 5-c). Offshore, the eastward oxygen transport across the western margin weakens during the La Niña events. Oxygen transport along the southern margin, which is mainly poleward during La Niña events, contributes to the drawdown of oxygen in the OMZ.

Temporal fluctuations in oxygen consumption show two distinct patterns: in the onshore region influenced by ENSO variability (blue line in Figure 6-d) and offshore without a clear relation to ENSO variability (blue line in Figure 7-d). Onshore, oxygen consumption appears enhanced during El Niño events and is comparable to the consumption during La Niña years (Figure 6-d), despite reduced biological productivity due to reduction in nutrient availability during El Niño events (EspinozaMorriberón et al., 2017). Moreover, the magnitude of oxygen consumption during biogeochemical processes is extremely weak compared to lateral and vertical oxygen supply by ocean dynamics. These fluctuations in oxygen consumption fail to explain the increased oxygen concentrations within the SWL (Figure 4-c,d) and the reduced SW volume (Figure 4-a,b). Oxygen pro- 
Biogeosciences Discuss., https://doi.org/10.5194/bg-2019-155

Manuscript under review for journal Biogeosciences

Discussion started: 2 May 2019

(c) Author(s) 2019. CC BY 4.0 License.

duction by phytoplankton within the SWL is close to zero in both onshore and offshore regions without regard to ENSO and non-ENSO years (red line in Figure 6-d), due to weak to no phytoplankton production in those layers (Espinoza-Morriberón et al., 2017).

\section{Discussions}

5 Using a coupled physical-biogeochemical model, we have successfully simulated oxygen variability in the ETSP. A good agreement is found between simulated oxygen variability and the in situ measurements recorded off Peru (Hamersley et al., 2007; Dale et al., 2017; Graco et al., 2017), proving to be a useful tool for understanding oxygen response to ENSO fluctuations. Our results suggest that the effects of ENSO fluctuations on ocean dynamics of the ETSP greatly alter oxygen distribution in the water column and therefore the vertical extension of the OMZ. In the simulated dynamics, the water column oxygen concentration of both onshore and offshore regions (Figure 4-c,d) appears increased during El Niño events (SST $>0.5^{\circ} \mathrm{C}$ ), when compared to the periods of La Niña events $\left(\mathrm{SST}<-0.5^{\circ} \mathrm{C}\right)$ and years not controlled by ENSO fluctuations i.e. normal conditions (SST $\pm 0.5^{\circ} \mathrm{C}$, Figure 3-a). Significant oxygen increase occurs during the 1997/1998 El Niño event and agrees with the measured values along the Peruvian shelf around $12^{\circ} \mathrm{S}$ (Hamersley et al., 2007; Graco et al., 2017). The increase of water column oxygen concentration during El Niño events leads to a reduction of SW volume in both onshore (Figure 4a) and offshore (Figure 4-b) regions of the ETSP OMZ. This reduction of SW volume, which reflects the reduction of the most oxygen-poor waters (with concentrations below $5 \mu \mathrm{mol} .1^{-1}$, Figure 4-c,d), is due to changes in supply of oxygenated waters from the lateral margins (Figure 6 and Figure 7). In the early stage of every El Niño event, oxygenated waters from the subtropical region are transported northward across the southern margin of the SWL in both onshore (Figure 6-b) and offshore (Figure 7-b) regions. This is consistent with Llanillo et al. (2018) who, using climatological annual-mean observed data, have found a contribution of subtropical pathway on oxygen supply into the ETSP OMZ. According to Llanillo et al. (2018) the subtropical pathway, which is related to the northward PCC along the coast and subtropical gyre meridional flow, is one of the main routes for oxygen supply at intermediated layers of the OMZ in the ETSP and contributes to around 70\% of the net oxygen supply at the layers with oxygen below $60 \mu \mathrm{mol} .1^{-1}$. The contribution of the subtropical waters to the OMZ was also been reported in the tropical North Atlantic OMZ (NA-OMZ), where 50\% of the subtropical origin waters reach the core depth of the OMZ (Peña-Izquierdo et al., 2015). Moreover, the intensity of the subtropical waters supply vary from one El Niño event to the other (Figure 6 and Figure 7) and does not show clear relation with El Niño type (Yu and Kim, 2013) or variety (Hu et al., 2018). For example, the supply of subtropical waters during the 1991/1992 coastal El Niño event is comparable with the supply during the1995/1996 which is not a coastal El Niño event. Conversely, oxygen supply from the tropical pathway weakens in the early stage of every El Niño event. The weakening of the oxygen supply, suggest a weakening of the EUC as well as the primary and secondary Southern Subsurface Countercurrent which bring eastward well oxygenated tropical waters (Llanillo et al., 2018). This suggestion is supported by in situ observations along the Equatorial region, which show a nearly disappearance of the EUC during 1982/1983 and 2015/2016 strong El Niño event (Firing et al., 1983; Stramma et al., 2016). Tropical pathway becomes effective in supplying oxygenated waters in the late stage of the El Niño events, when the supply 
Biogeosciences Discuss., https://doi.org/10.5194/bg-2019-155

Manuscript under review for journal Biogeosciences

Discussion started: 2 May 2019

(c) Author(s) 2019. CC BY 4.0 License.

of subtropical waters weakens. This pattern suggest that the weakening of the oxygen supply by tropical pathway in the early stage of El Niño event favors the oxygen supply from the subtropics. Similar patterns have been reported in the NA-OMZ, where Peña-Izquierdo et al. (2015) found a drastic weakening of the tropical pathway in favor of a subtropical pathway. The northern margin of the SW is another paths for oxygen supply from the early stage of El Niño event. However, this pathway is significant offshore and during the strong (1991/1992) and very strong (1997/1998) El Niño events.

In contrast to El Niño events, oxygen transport across the southern margin is predominately poleward during La Niña events, limiting the northward propagation of subtropical oxygenated waters. Thus, the tropical-equatorial oxygenated waters are injected into the OMZ. Despite this supply of tropical-equatorial oxygenated waters, the volume of SW is higher than the SW volume during El Niño events. Those findings suggest that the subtropical pathway is essential part of the ventilation of the ETSP OMZ.

\section{Conclusion}

Observations recorded along the Peruvian and Chilean coast have shown strong water column oxygenation during 1997/1998 El Niño event. These findings have suggested an influence of ENSO variability on the vertical extent of the oxygen-poor waters (Sanchez et al., 1999; Hamersley et al., 2007; Graco et al., 2017), with a reduction of the OMZ area off Peru and northern Chile by up to $61 \%$ (Helly and Levin, 2004). Here, analysing large-scale and long-term simulated ocean dynamics under realistic atmospheric forcing, we have added further insights into the influence of ENSO variability on OMZ dynamics in the ETSP. Our analysis shows a deepening of oxycline and a shoaling of the upper boundary of the SW layer during El Niño events, as observed along the Peruvian and Chilean coast during the 1997/1998 strong El Niño event (Hamersley et al., 2007; Graco et al., 2017). This SW response is a common feature for every El Niño phase simulated by our model during the period 1990-2010, regardless of their intensity. Our results further indicate a narrowing of the SWL under El Niño influence. These changes in SW dynamics are the consequences of the supply of equatorial, tropical and subtropical oxygenated waters from the lateral margins. The reduction of SW volume is triggered by the enhanced supply of oxygen via the subtropical pathway during the El Niño events. Contrarily, under La Niña influence, the SWL widens and its upper margin shoals, caused by a reduction of oxygen supply mainly from the subtropical gyre. As a consequence, the oxygen concentration within the SWL declines and the suboxic conditions intensify.

Dynamics along the interface between south Pacific subtropical gyre and OMZ appear to be crucial in the ventilation of the ETSP-OMZ. Understanding the variability in the subtropical gyre is essential to assess the variability of the ETSP OMZ. Further, ENSO-driven fluctuations in oxygen consumption due to the switch between aerobic and anaerobic remineralization of organic matter might possibly trigger changes in water column nutrient budgets. Understanding and quantifying this feedback can be useful on quantification of nutrient budget of the ETSP. 
Biogeosciences Discuss., https://doi.org/10.5194/bg-2019-155

Manuscript under review for journal Biogeosciences

Discussion started: 2 May 2019

(c) Author(s) 2019. CC BY 4.0 License.

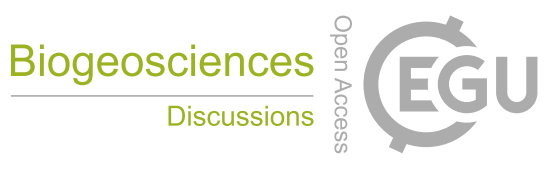

(c) (i)

\section{Code availability}

CROCO and BioEBUs models are available at http://www.croco-ocean.org

\section{Data availability}

The model data used in this paper are available via the corresponding author

5 Acknowledgements. This work is financially supported by the Deutsche Forschungsgemeinschaft (DFG), under the Sonderforschungsbereich 754 "Climate-Biogeochemistry Interactions in the Tropical Ocean" (www.sfb754.de). Simulations were performed using the computing facilities of the Norddeutscher Verbund zur Förderung des Hoch- und Höchstleistungsrechnen - HLRN. The in situ circulation data were kindly provided by IMARPE (Instituto del Mar del Peru). Nino1+2 and Nino3 SST indices were provided by the NOAA (National Oceanic and Atmospheric Administration, USA), downloaded from their Web site at https://stateoftheocean.osmc.noaa.gov/sur/pac in December 102018. 
Biogeosciences Discuss., https://doi.org/10.5194/bg-2019-155

Manuscript under review for journal Biogeosciences

Discussion started: 2 May 2019

(c) Author(s) 2019. CC BY 4.0 License.

\section{References}

Atlas, R., Hoffman, R.N., Bloom, S.C., Jusem, J.C., and Ardizzone, J.: A multiyear global surface wind velocity dataset using SSM/I wind observations, Bull. Amer. Meteor. Soc., 77, https://doi.org/10.1175/1520-0477(1996)077<0869:AMGSWV>2.0.CO;2, 1996.

Barber, R. T., and Chavez, F. P.: Biological consequences of El Niño, Science, 222, doi:10.1126/science.222.4629.1203, 1983.

Carton, J. A., Chepurin, G. A., and Chen, L.: SODA3: a new ocean climate reanalysis, J. Climate, 31, https://doi.org/10.1175/JCLI-D-18$0149.1,2018$.

Chaigneau, A., Dominguez, N., Eldin, G., Vasquez, L., Flores, R., Grados, C., and Echevin, V.: Near-coastal circulation in the Northern Humboldt Current System from shipboard ADCP data, J. Geophys. Res., 118, https://doi.org/10.1002/jgrc.20328, 2013.

Chavez, F. P., Bertrand, A., Guevara-Carrasco, R., Soler R. P., and Csirke, J.: The northern Humboldt Current System: Brief history, present status and a view towards the future, Progress in Oceanography, 79, doi:10.1016/j.pocean.2008.10.012, 2008.

Chavez, F. P., Strutton, P. G., Friederich, G. E., Feely, R. A., Feldman, G. C., Foley, D. G., and McPhaden, M. J.: Biological and Chemical Response of the Equatorial Pacific Ocean to the 1997-1998 El Niño, Science, 286, 2126-2131, doi:10.1126/science.286.5447.2126, 1999.

Czeschel, R., Stramma, L., Schwarzkopf, F. U., Giese, B. S., Funk, A. and Karstensen, J.: Middepth circulation of the eastern tropical South Pacific and its link to the oxygen minimum zone, J. Geophys. Res., 116, https://doi.org/10.1029/2010JC006565, 2011.

Czeschel, R., Stramma, L., Weller, R. A. and Fischer, T.: Circulation, eddies, oxygen, and nutrient changes in the eastern tropical South Pacific Ocean, Ocean Science, 11, https://doi.org/10.5194/os-11-455-2015, 2015.

Dale, A. W., Graco M., and Wallmann K.: Strong and dynamic benthic-pelagic coupling and feedbacks in a coastal upwelling system (Peruvian shelf), Front. Mar. Sci. 4, https://doi.org/10.3389/fmars.2017.00029, 2017.

Duteil, O., Schwarzkopf, F. U., Böning, C. W., and Oschlies A.: Major role of the equatorial current system in setting oxygen levels in the eastern tropical Atlantic Ocean: A high-resolution model study, Geophys. Res. Lett. 41, https://doi.org/10.1002/2013GL058888, 2014a.

Duteil, O., Böning, C. W., and Oschlies A.: Variability in subtropical-tropical cells drives oxygen levels in the tropical Pacific Ocean, Geophys. Res. Lett. 41, https://doi.org/10.1002/2014GL0617744, 2014b.

Escribano, R., Daneri, G., Farías, L., Gallardo, V. A., González, H. E., Gutieŕrez, D., Lange, C. B., Morales, C. E., Pizarro, O., Ulloa, O., and Braun, M.: Biological and chemical consequences of the 1997-1998 El Niño in the Chilean coastal upwelling system:a synthesis, Deep-Sea Research II, 51, https://doi.org/10.1016/j.dsr2.2004.08.011, 2004.

Espinoza-Morriberón, D., Echevin, V., Colas, F., Tam, J., Ledesma, J., Vasquez, L., and Graco, M.: Impacts of El Niño events on the Peruvian upwelling system productivity, J. Geophys. Res. Oceans 122, https://doi.org/10.1002/2016JC012439, 2017.

Firing, E., Lukas, R., Sadler, J., and Wyrtki, K.: Equatorial Undercurrent Disappears During 1982-1983 El Niño. Science, 222, doi:10.1126/science.222.4628.1121, 1983.

30 Graco, M., Purca, S., Dewitte,B., Castro, C.G., Morón, O., Ledesma, J., Flores, G., and Gutiérrez, D.: The OMZ and nutrient features as a signature of interannual and low-frequency variability in the Peruvian upwelling system, Biogeosciences, 14, https://doi.org/10.5194/bg14-4601-2017, 2017.

Graham, N. R. and White W. R.: Niño Cycle: A Natural Oscillator of the Pacific Ocean-Atmosphere System, Science, 240, doi:10.1126/science.240.4857.1293, 1988.

Gutknecht, E., Dadou, I., Le Vu, B., Cambon,G., Sudre, J., Garçon, V., Machu, E., Rixen, T., Kock, A., Flohr, A., Paulmier, A., and Lavik, G.: Coupled physical/biogeochemical modeling including O2-dependent processes in the Eastern Boundary Upwelling Systems: application in the Benguela, Biogeosciences, 10, doi:10.5194/bg-10-3559-2013, 2013. 
Biogeosciences Discuss., https://doi.org/10.5194/bg-2019-155

Manuscript under review for journal Biogeosciences

Discussion started: 2 May 2019

(c) Author(s) 2019. CC BY 4.0 License.

Hamersley, R., Lavik, G., Woebken, D., Rattray, J. E., Lam, P., Hopmans, E. C., Damsté, J. S. S., Krüger, S., Graco, M., Gutiérrez, D., and

Kuypers, M. M.: Anaerobic ammonium oxidation in the Peruvian oxygen minimum zone. Limnol. Oceanogr., $52,2007$.

Harisson, D. E., and Larkin, N. K.: El Niño-Southern Oscillation sea surface temperature and wind anomalies, 1946-1993, Reviews of

Geophysics, 36, https://doi.org/10.1029/98RG00715, 1998.

5 Helly, J. J., and Levin, L. A.: Global distribution of naturally occuring marine hypoxia on continental margins, Deep-Sea Res. I, 51, 1159$1168,2004$.

Hu, Z-Z., Huang, B., Zhu, J., Kumar, A., and McPhaden M. J.: On the variety of coastal El Niño events, Climate Dynamics https://doi.org/10.1007/, https://doi.org/10.1007/s00382-018-4290-4, 2018.

Karstensen, J., Stramma, L., and Visbeck, M.: Oxygen minimum zones in the eastern tropical Atlantic and Pacific oceans, Progress in Oceanography, 77, doi:10.1016/j.pocean.2007.05.009, 2008.

Kilpatrick, K.A. , Podestá, G., Walsh, S., Williams, E., Halliwell, V., Szczodrak, M., Brown, O. B., Minnett, P.J., and Evans, R.: A decade of sea surface temperature from MODIS, Remote Sensing of Environment, Remote Sensing of Environment, 165, http://dx.doi.org/10.1016/j.rse.2015.04.023, 2015.

Llanillo, J. P. , Pelegri, J. L., Talley, L. D., Penã-Izquierdo, J., and Cordero, R. R.: Oxygen Pathways and Budget for the Eastern South Pacific Oxygen Minimum Zone, J. Geophys. Res.: Oceans, 123, https://doi.org/10.1002/2017JC013509, 2018.

Montes, I., Schneider, W., Colas, F., Blanke, B., and Echevin, V.: Subsurface connections in the eastern tropical Pacific during La Niña 1999-2001 and El Niño 2002-2003, J. Geophys. Res., 116, https://doi.org/10.1029/2011JC007624, 2011.

Peña-Izquierdo, J., van Sebille, E., Pelegrí, J. L., Sprintall, J., Mason, E., Llanillo, P. J., and Machín, F.: Water mass pathways to the North Atlantic oxygen minimum zone, J. Geophys. Res. Oceans, 120, https://doi.org/10.1002/2014JC010557, 2015.

Philander, S. G. H.: El Niño Southern Oscillation phenomena, Nature, 302, doi:10.1038/302295a0, 1983.

Pizarro, O., Shaffer, G., Dewitte, B., and Ramos, R.: Dynamics of seasonal and interannual variability of the Peru-Chile Undercurrent, Geophys. Res. Lett., 29, https://doi.org/10.1029/2002GL014790, 2002.

Reynolds, R. W., Rayner, N., A., Smith, T. M., Stokes, D. C., and Wang, W.: An Improved In Situ and Satellite SST Analysis for Climate, J. of Climate, 15, 2002.

25 Ridgway, K. R., Dunn J. R., and Wilkin, J. L.: Ocean interpolation by four-dimensional weighted least Squares-Application to the waters around Australia, J. Atmospheric and Oceanic Technol., 19, https://doi.org/10.1175/1520-0426(2002)019<1357:OIBFDW>2.0.CO;2, 2002.

Rio, M. H, Mulet, S., and Picot, N.: New global mean dynamic topography from a GOCE GEOID model, altimeter measurements and oceanographic in-situ data, Proc. 'ESA Living Planet Symposium, 1-7, 2013.

Saha, S., Moorthi, S., Pan, H., Wu, X., Wang, J., Nadiga, S., Tripp, P., Kistler, R., Woollen, J., Behringer, D., Liu, H., Stokes, D., Grumbine, R., Gayno, G., Wang, J., Hou, Y., Chuang, H., Juang, H. H., Sela, J., Iredell, M., Treadon, R., Kleist D., Delst, P., Keyser, D., Derber, J., Ek, M., Meng, J., Wei, H., Yang, R., Lord, S., Dool, H., Kumar, A., Wang, W., Long, C., Chelliah, M., Xue, Y., Huang, B., Schemm, J., Ebisuzaki, W., Lin, R., Xie, P., Chen, M., Zhou, S., Higgins, W., Zou, C., Liu, Q., Chen, Y., Han, Y., Cucurull, L., Reynolds, R. W., Rutledge, G., and Goldberg, M.: The NCEP Climate Forecast System Reanalysis, Bull. Am. Meteorol. Soc., 91 https://doi.org/10.1175/2010BAMS3001.1, 2010.

Sanchez, G., Calienes, R., and Zuta, S.: The 1997-98 El Niño and its effect on the marine coastal system off Peru, CALCOFI Reports, 41, 62-86, 1999. 
Biogeosciences Discuss., https://doi.org/10.5194/bg-2019-155

Manuscript under review for journal Biogeosciences

Discussion started: 2 May 2019

(c) Author(s) 2019. CC BY 4.0 License.

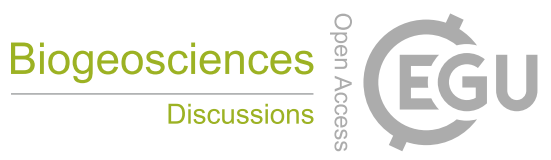

(c) (i)

Shchepetkin, A. F., and McWilliams, J. C.: The regional oceanic modeling system (ROMS): a split-explicit, free-surface, topographyfollowing-coordinate oceanic model, Ocean modelling, 19, https://doi.org/10.1016/j.ocemod.2004.08.002, 2005.

Song, Y., and Haidvogel D. B.: A semi-implicit ocean circulation model using a generalized topography-following coordinate system, J. Comp. Phys. 115, https://doi.org/10.1006/jcph.1994.1189, 1994.

5 Stramma, L., Johnson, G. C., Sprintall, J., and Mohrholz, V.: Expanding Oxygen-Minimum Zones in the Tropical Oceans, Science, 320, 2008.

Stramma, L., Johnson, G. C., Firing, E., and Schmidtko, S.: Eastern Pacific oxygen minimum zones: Supply paths and multidecadal changes, J. Geophys. Res. 115 https://doi.org/10.1029/2009JC005976, 2010.

Stramma, L., Fischer, T., Grundle, D. S., Krahmann, G., Bange, H. W., and Marandino, C. A.: Observed El Niño conditions in the eastern tropical Pacific in October 2015, Ocean Sci., 12, https://doi.org/10.5194/os-12-861-2016, 2016.

White, W. R., and Cayan, D. R.: A global El Niño-Southern Oscillation wave in surface temperature and pressure and its interdecadal modulation from 1900 to 1997, J. Geophys. Res., 105, https://doi.org/10.1029/1999JC900246, 2000.

Yu, J-Y and Kim, S. T.: Identifying the types of major El Niño events since 1870, Int. J. Climatol. 33, https://doi.org/10.1002/joc.3575, 2013 
Biogeosciences Discuss., https://doi.org/10.5194/bg-2019-155

Manuscript under review for journal Biogeosciences

Discussion started: 2 May 2019

(C) Author(s) 2019. CC BY 4.0 License.

(a)

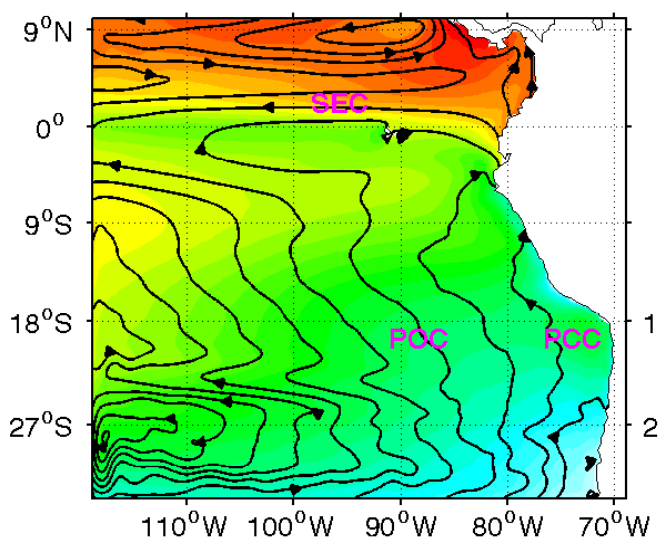

(b) Observation

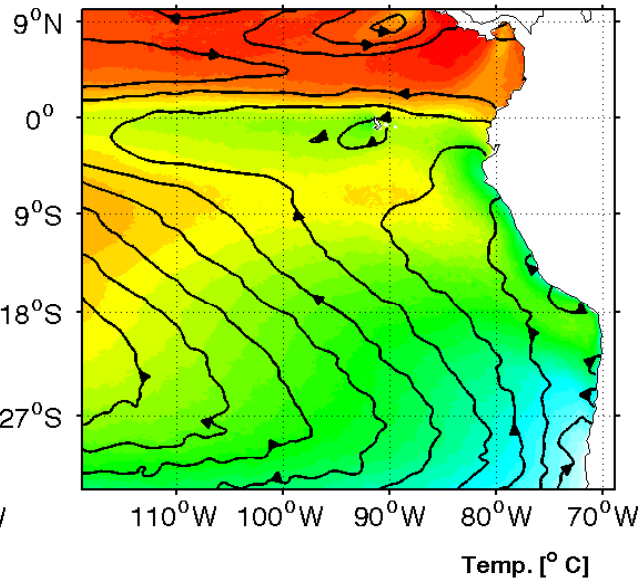

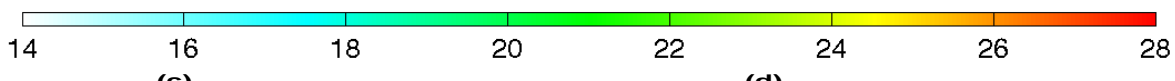
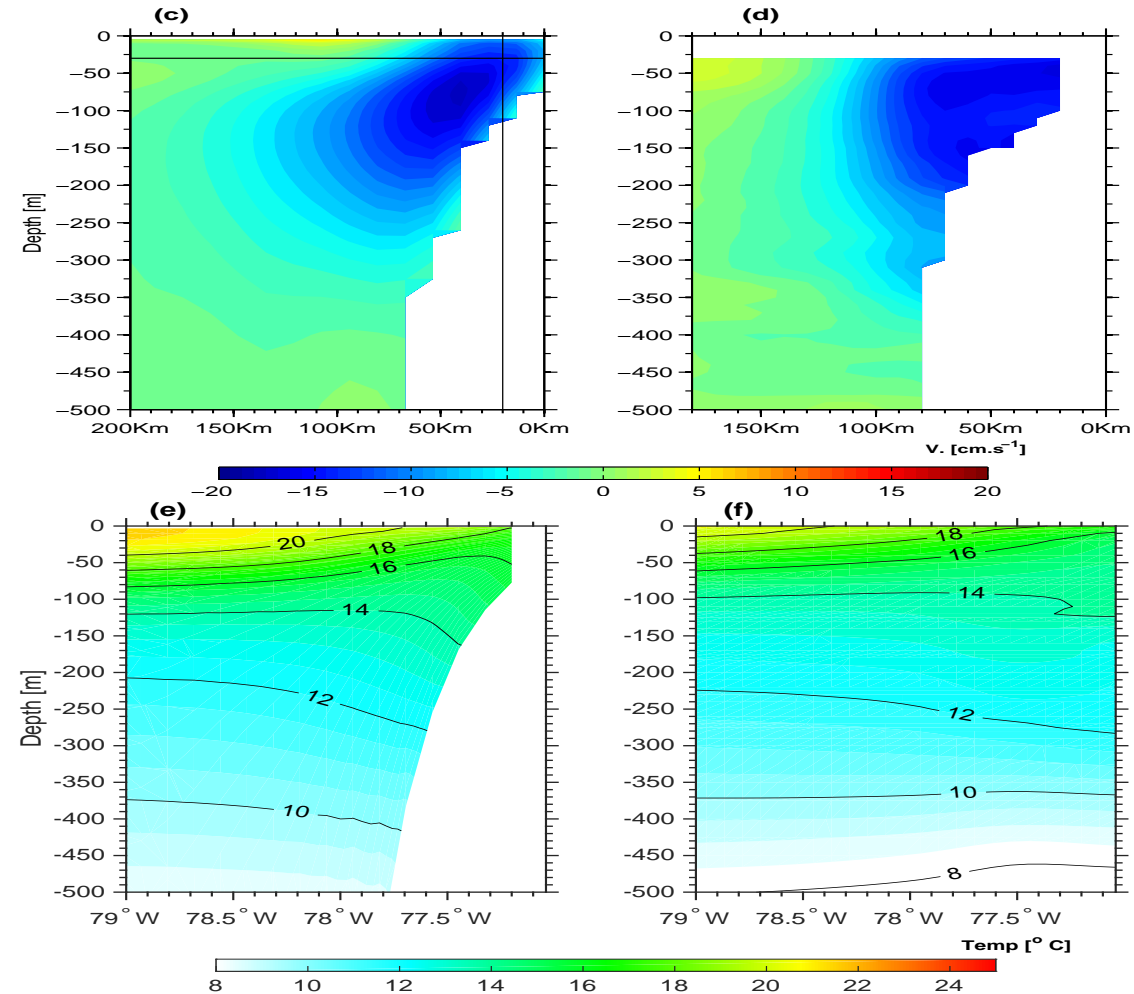

Figure 1. Simulated (left panels) and observed (right panels) physical dynamics in the ETSP. (a,b) Surface circulation pattern (contour every $5 \mathrm{~cm}$ of the mean sea surface height) and sea surface temperature (color, $\left.\left[{ }^{\circ} \mathrm{C}\right]\right) .(\mathrm{c}, \mathrm{d})$ Alongshore current $\left(\left[\mathrm{cm} \cdot \mathrm{s}^{-1}\right]\right.$, positive northward) and (e,f) vertical structure of temperature $\left[{ }^{\circ} \mathrm{C}\right]$ around $12^{\circ} \mathrm{S}$ along the Peruvian shelf. Observed data are from CNES (contours in b), MODIS (color in b), IMARPE (d) and CARS (f). Horizontal and vertical lines in (c) indicate the spatial delimitation of the in situ observed currents. Simulated dynamics correspond to the mean state obtained by averaging the fields over 1990-2010 period. SEC, POC and PCC acronyms in (a) indicate the westward South Equatorial Current, north-westward Peru Oceanic current and northward Peru Coastal Current respectively. 
Biogeosciences Discuss., https://doi.org/10.5194/bg-2019-155

Manuscript under review for journal Biogeosciences

Discussion started: 2 May 2019

(C) Author(s) 2019. CC BY 4.0 License.
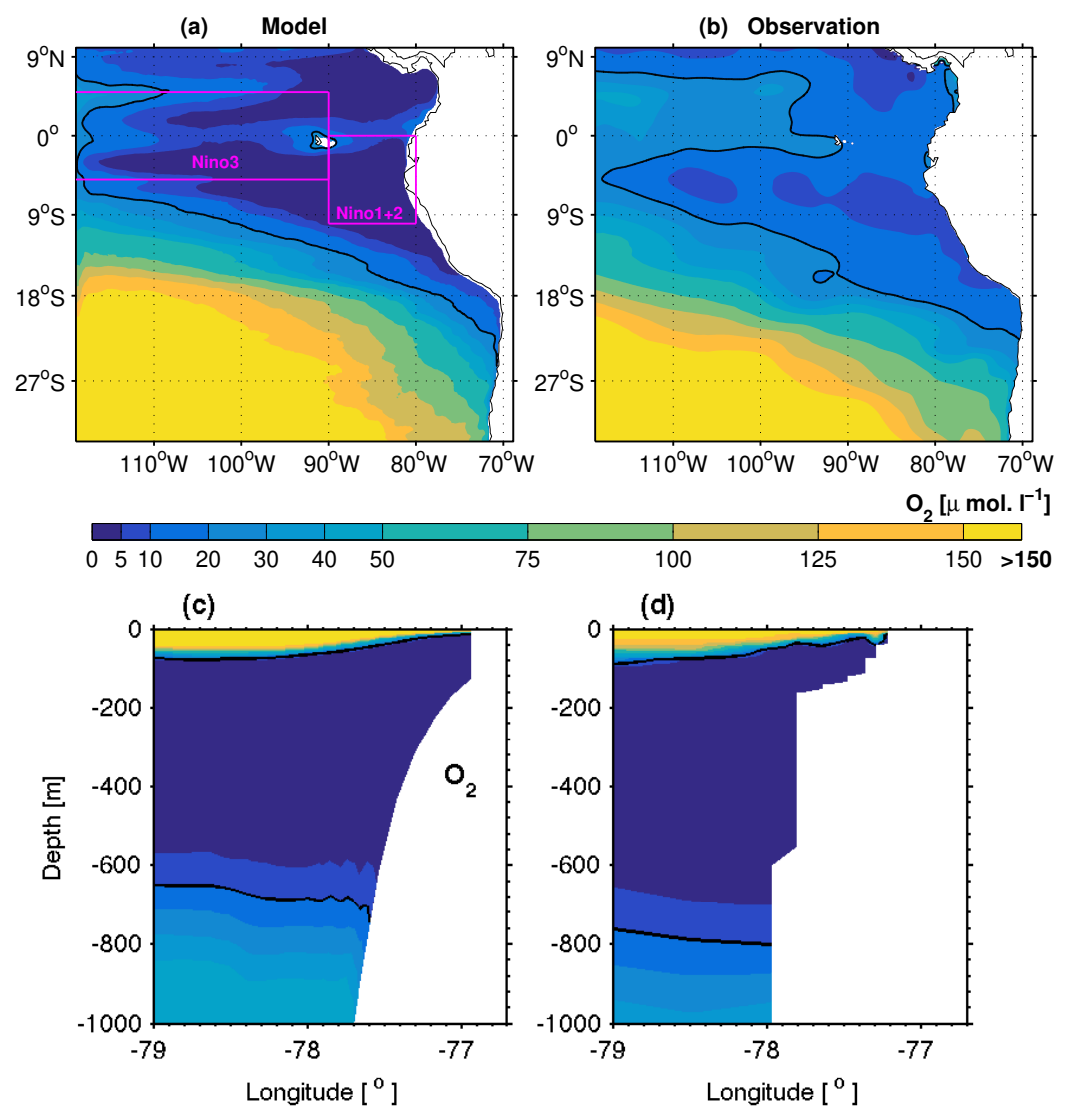

Figure 2. Simulated (left panels) and observed (right panels) oxygen concentration. (a,b) Oxygen concentration at $400 \mathrm{~m}$ depth. (c,d) Vertical structure of oxygen at $12^{\circ} \mathrm{S}$ along the Peruvian shelf. Observed data are from CARS (b) and M91 cruise in December 2012 (d). Simulated dynamics correspond to the (a) mean state and (c) December month, obtained by averaging the fields over 1990-2010 period and year 2010 respectively. Black contours in a,b,c,d mark the $20 \mu$ mol.1 $1^{-1}$ oxygen isoline. Magenta lines in (a) correspond to Nino1+2 and Nino3 regions. 
Biogeosciences Discuss., https://doi.org/10.5194/bg-2019-155

Manuscript under review for journal Biogeosciences

Discussion started: 2 May 2019

(c) Author(s) 2019. CC BY 4.0 License.

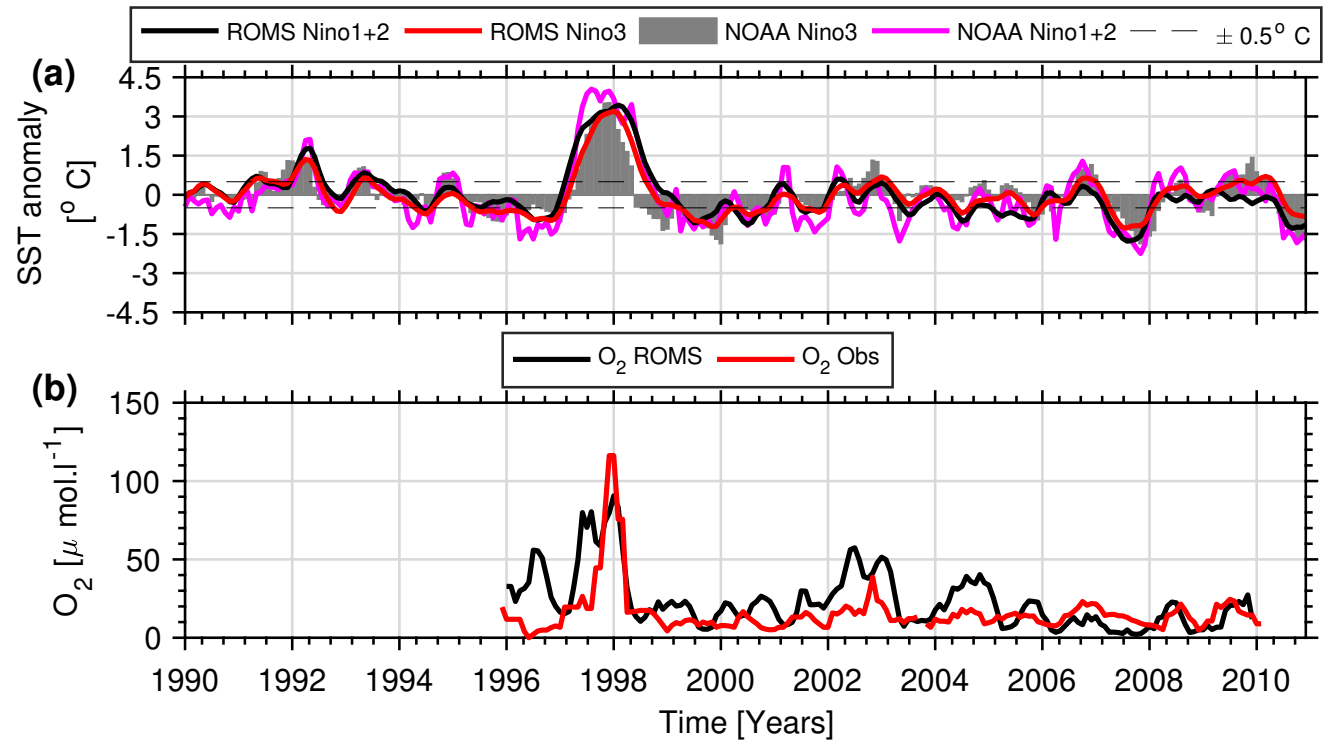

Figure 3. (a) Interannual variability of simulated sea surface temperature anomaly from the regional model CROCO (black and red lines) and NOAA dataset (gray bars and magenta line, Reynolds et al. (2002)). (b) Interannual variability of oxygen concentration [ $\mu$ mol.1 ${ }^{-1}$ ] between 90 and $100 \mathrm{~m}$ depth at $12^{\circ} \mathrm{S}$ along the Peruvian shelf from the regional model CROCO (black line) and IMARPE in situ observations (red line, Dale et al. (2017)). NOAA SST anomaly Reynolds et al. (2002) correspond to dynamics at Nino $1+2\left(0-10^{\circ} \mathrm{S}\right.$ and $80-90^{\circ} \mathrm{W}$, magenta line in Figure 3-a) and Nino $3\left(5^{\circ} \mathrm{N}-5^{\circ} \mathrm{S}\right.$ and $90-120^{\circ} \mathrm{W}$, gray bars in Figure 3-a) regions shown in magenta lines in Figure 2-a. Simulated Nino 3 dynamics is the averaged SST from $5^{\circ} \mathrm{N}-5^{\circ} \mathrm{S}$ and $90-115^{\circ} \mathrm{W}$. Black dashed lines indicates SST anomaly $\pm 0.5^{\circ} \mathrm{C}$ 
Biogeosciences Discuss., https://doi.org/10.5194/bg-2019-155

Manuscript under review for journal Biogeosciences

Biogeosciences

Discussion started: 2 May 2019

Discussions

(c) Author(s) 2019. CC BY 4.0 License.

(c) (1)
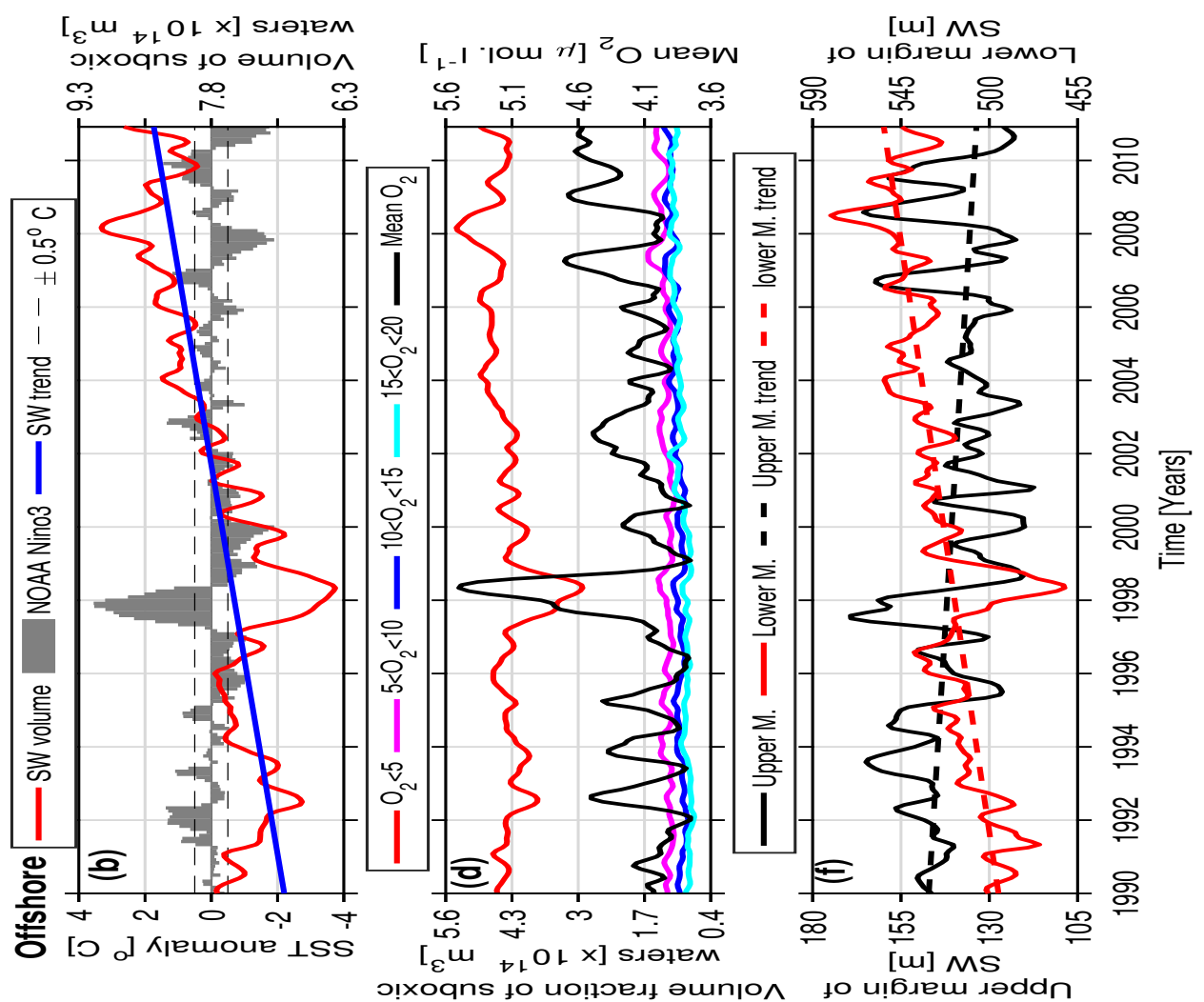

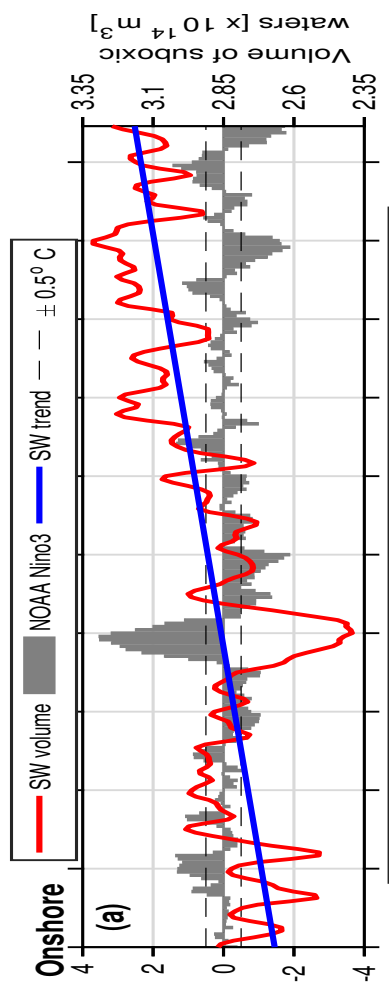

[0 d kpewour LSS
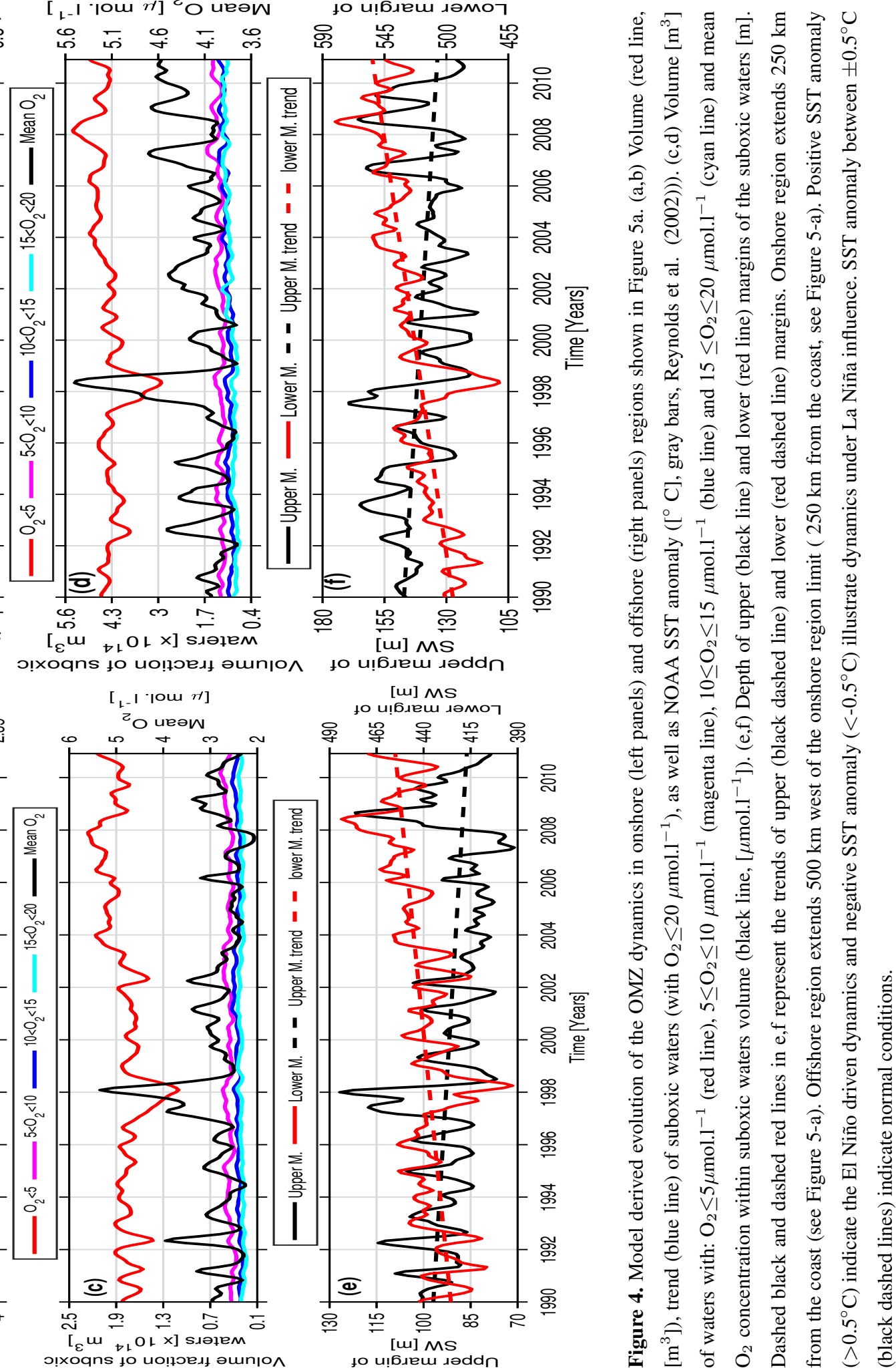
Biogeosciences Discuss., https://doi.org/10.5194/bg-2019-155

Manuscript under review for journal Biogeosciences

Discussion started: 2 May 2019

(c) Author(s) 2019. CC BY 4.0 License.
Biogeosciences

Discussions

\section{(c) (1)}
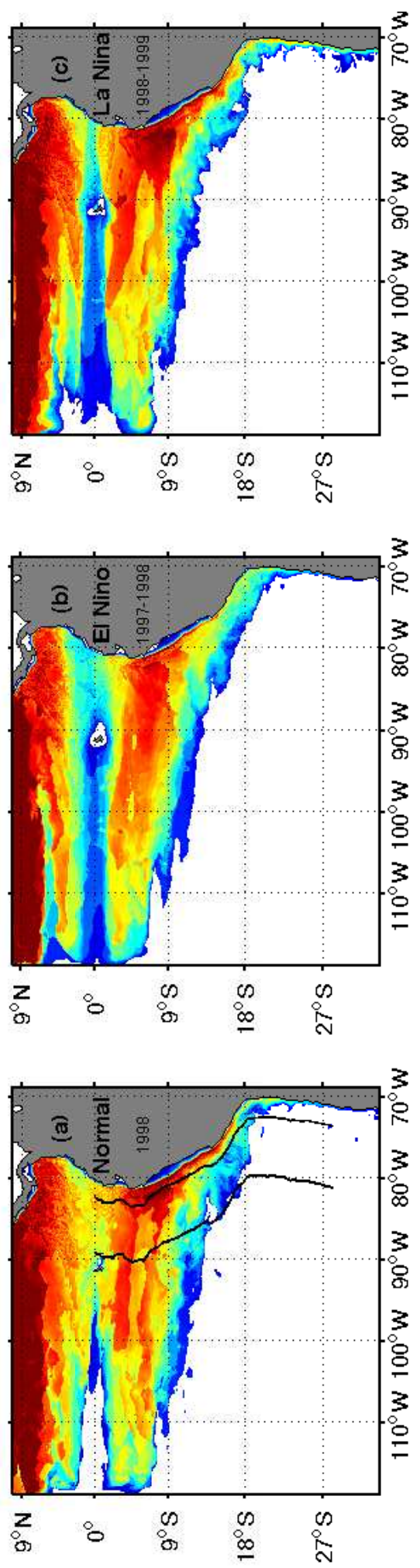

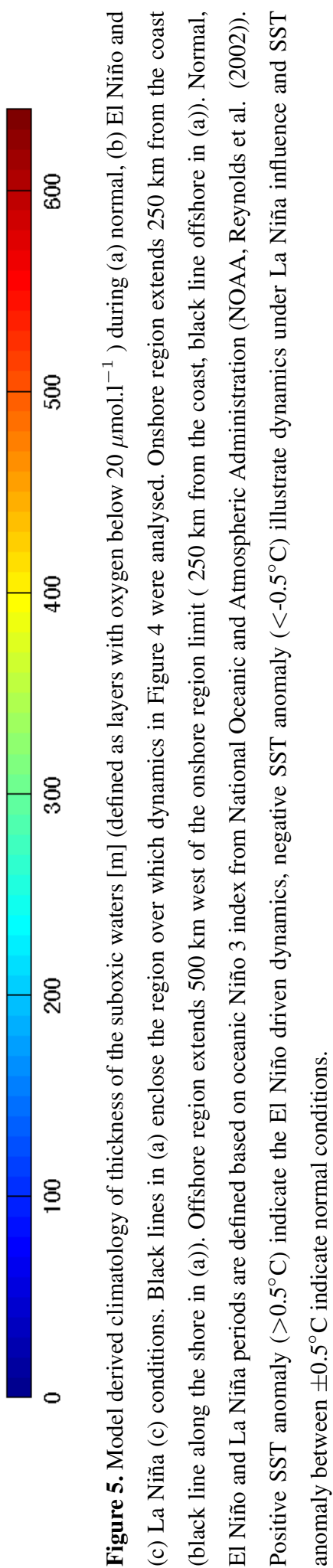


Biogeosciences Discuss., https://doi.org/10.5194/bg-2019-155

Manuscript under review for journal Biogeosciences

Discussion started: 2 May 2019

(c) Author(s) 2019. CC BY 4.0 License.

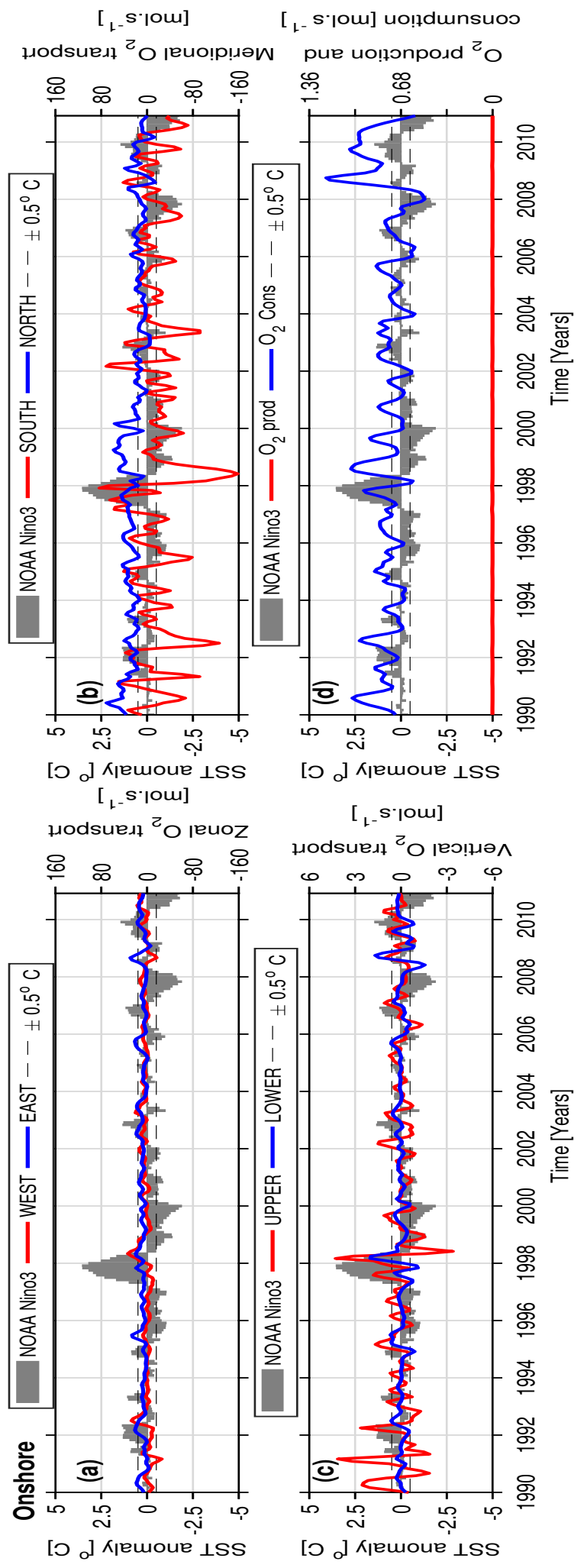

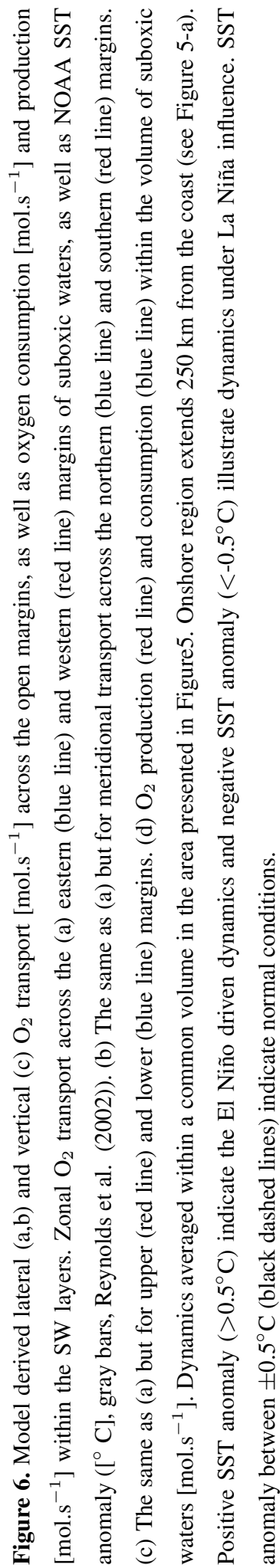


Biogeosciences Discuss., https://doi.org/10.5194/bg-2019-155

Manuscript under review for journal Biogeosciences

Discussion started: 2 May 2019

(c) Author(s) 2019. CC BY 4.0 License.

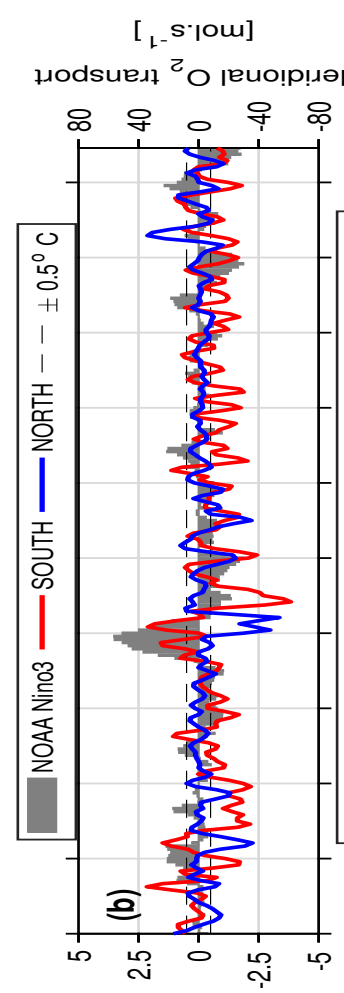

[0 ] Newour $\perp S S$

[ $\mathrm{L}^{\mathrm{s}}$.

hodsuen ${ }^{2} \mathrm{O}$ jeuOZ

[ L- S`jom] uo!!dunsuoo

pue uo!lonposd ${ }^{2} \mathrm{O}$

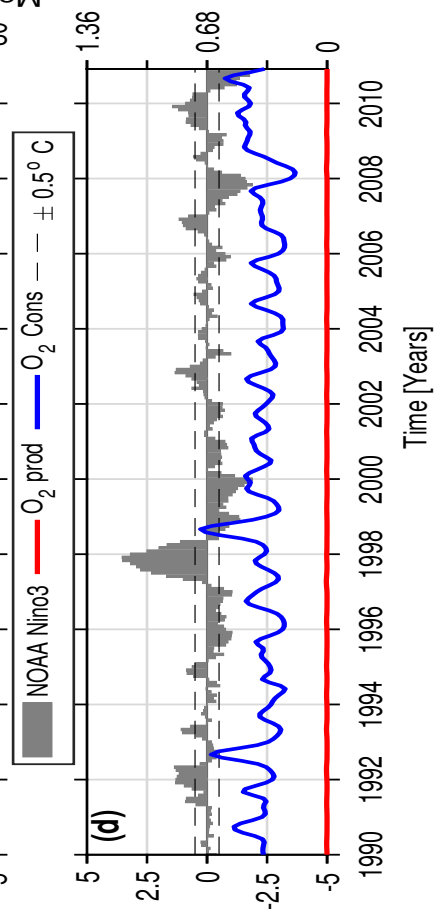

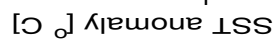

[ [- s.jom]

hodsuent ${ }^{\mathrm{O}} \mathrm{O}$ ןеo!nan
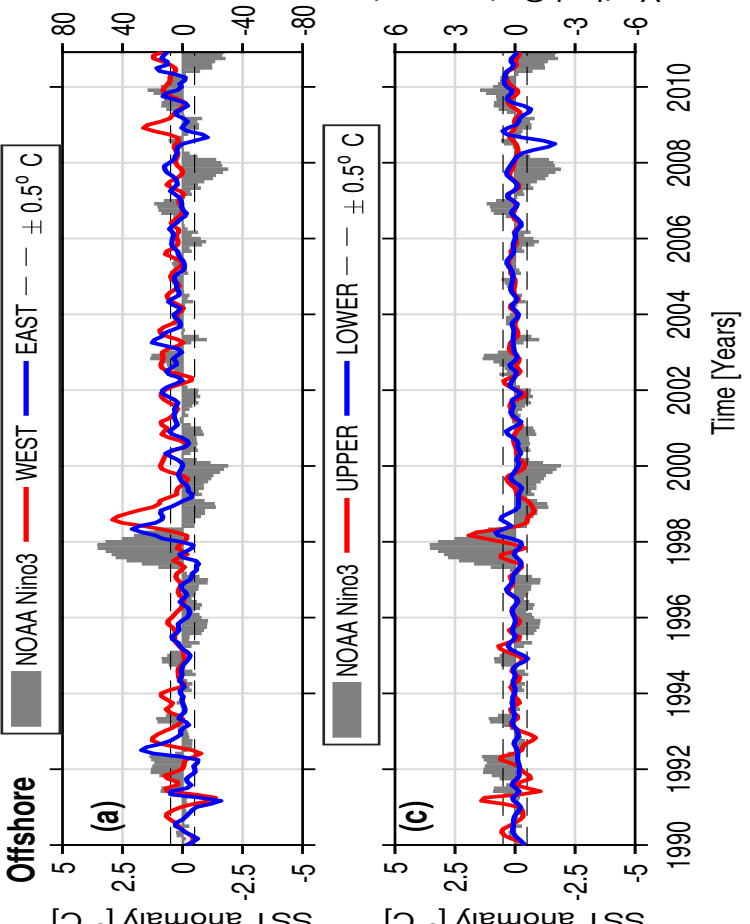

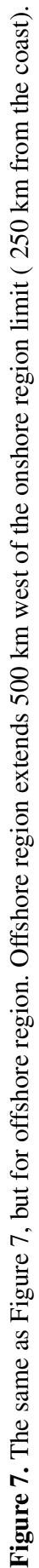

